\title{
Towards the anti-fibrillogenic activity of phthalocyanines with out-of-plane ligands: correlation with self-association proneness
}

\author{
V. B. Kovalska ${ }^{1}$, M. Yu. Losytskyy ${ }^{1}$, S. V. Chernii ${ }^{1}$, V. Ya. Cherniii ${ }^{2}$,
}

I. M. Tretyakova', S. M. Yarmoluk ${ }^{1}$, S. V. Volkov ${ }^{2}$

${ }^{1}$ Institute of Molecular Biology and Genetics, NAS of Ukraine

150, Akademika Zabolotnoho Str., Kyiv, Ukraine, 03680

${ }^{2}$ Vernadsky Institute of General and Inorganic Chemistry, NAS of Ukraine

32/34, Prospekt Akademika Palladina, Kyiv, Ukraine, 03142

v.kovalska@gmail.com

\begin{abstract}
Aim. The activity of five hafnium phthalocyanines containing out-of-plane ligands as inhibitors of reaction of insulin fibril formation is studied and correlation between their inhibitory properties and tendency to selfassociation is discussed. Methods. Fluorescence and absorption spectroscopy. Results. For the complexes with weak proneness to self-association PcHfDbm, PcHfPyr, and PcHfBtfa, the values of inhibitory activity were estimated as 60-73\%. For phthalocyanines with the pronounced tendency to self-association PcHfPiromelit and $\mathrm{PcHfCl}$, the noticeably higher inhibitory activity values (about $95 \%$ ) were shown. In the presence of native or fibrilar insulin the destruction of self-associates of metal complex occurs in buffer $\mathrm{pH} 7.9$, Besides upon the conditions of insulin fibrillization reaction $(0.1 \mathrm{M} \mathrm{HCl})$ phthalocyanines exist predominantly as monomers. Conclusions. The phthalocyanines with out-of-plane ligands with higher tendency to self-association have shown higher inhibitory activity in the insulin fibril formation comparing with the poorly aggregated metal complexes. At the same time low-order self-associates are not involved directly in th] mechanism of inhibition of insulin fibrillization and the phthalocyanines bind with protein in monomeric form. Tendency of phthalocyanines to self-association in aqueous media seems to be an «indicator» of their proneness to stack with protein aromatic amino-acids and thus of anti-fibrilogenic properties.
\end{abstract}

Keywords: amyloid fibril, phthalocyanines, inhibitors of fibril formation, insulin, aggregation of phthalocyanines, fluorescent dye.

Introduction. Pathogenesis of many diseases, including neurodegenerative disorders (Alzheimer's, Parkinson's, Huntington's chorea) is accompanied by formation of the $\beta$-pleated aggregates of proteins, so-called amyloid fibrils [1]. In each of these pathological conditions specific proteins or protein fragments alter the natural soluble form to insoluble fibrils that accumulate in various organs and tissues [2].

Among the compounds able to suppress the amyloid fibril formation, planar macrocyclic metal complexes phthalocyanines were reported [3]. Due to their high in-

(C) Institute of Molecular Biology and Genetics, NAS of Ukraine, 2013 hibitory activity, low toxicity and ability to overcome blood-brain barrier [4], the compounds of this class are considered as prospective anti-fibrillogenic agents.

Among the properties that could affect the anti-fibrillogenic and anti-prion activity of phthalocyanines is the tendency of metal complex to self-association [5, 6]. Lamberto et al. have shown that the differences in binding capacity and anti-amyloid activity of phthalocyanines towards alpha-synuclein are attributed to their relative ability to self-stack through $\pi-\pi$ interactions modulated by the nature of a metal ion. The low order stacked aggregates of phthalocyanines were identified as the active amyloid inhibitory species [5]. 


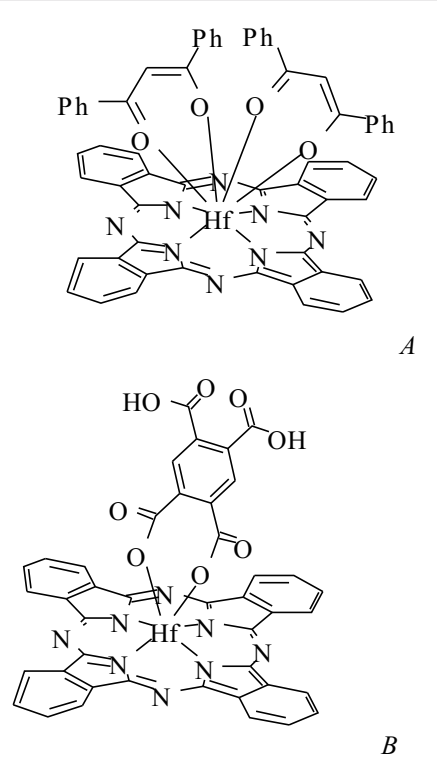

$B$

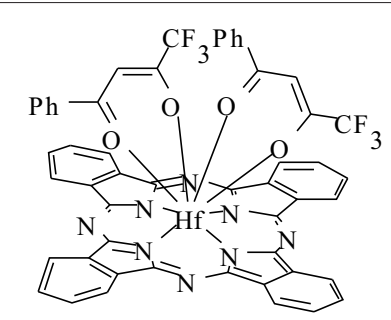

C

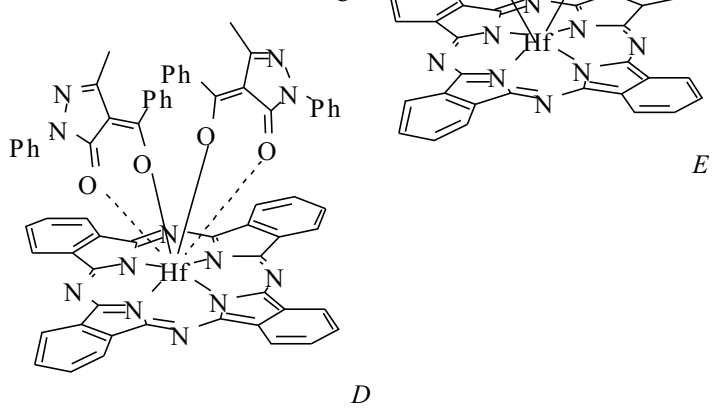

Fig. 1. Chemical structure of hafnium phthalocyanine with out-of-plane ligands: dibenzoylmethane $\left(A-\mathrm{PcHfDbm}_{2}\right)$; pyromellitic acid $(B-\mathrm{PcHf}$ Piromelit); benzoyl-1,1,1-trifluoroacetone ( $\left.C-\mathrm{PcHfBtfa}_{2}\right)$; 1-phenyl-3-methyl-4-benzoylpyrazolone-5 ( $\left.D-\mathrm{PcHfPyr}_{2}\right)$; chlorine atoms $\left(E-\mathrm{PcHfCl}_{2}\right)$
Recently the anti-fibrillogenic activity of phthalocyanines with out-of-plane ligands has been reported [7]. In contrast to usually planar porphyrine and phthalocyanine molecules these metal complexes have a steric content due to the presence of out-of-plane ligands bound to the central metal atom. These complexes are able to inhibit the reaction of insulin fibrillization and to redirect its pathway to the formation of oligomeric aggregates [7].

The current work is aimed at studying the inhibitory activity of series of five hafnium phthalocyanines containing out-of-plane ligands of various chemical nature (Fig. 1) in the reaction of insulin fibrillization and at inquiring into the role of phthalocyanines self-association in anti-fibrillogenic properties. The inhibitory activity of metal complexes is determined using earlier reported fluorescent cyanine based inhibitory assay [8]. For the study on phthalocyanines self-association the absorption spectra were obtained for both free metal complexes and in the presence of native and fibrillar insulin.

Materials and methods. Hafnium phthalocyanines with out-of-plane ligands were synthesized as described in [9-11]. These compounds were of intensive greenblue color and had moderate solubility in DMF. Phthalocyanines were stable under the experimental conditions. Composition and structure of complexes were confirmed by ${ }^{1} \mathrm{H}$ NMR and element analysis on metal. Stock solutions of phthalocyanines in concentration of $2 \mathrm{mM}$ were prepared by dissolving the compound in DMF. Amyloid-specific cyanine dye 7519 [12] was kindly pro- vided by Dr. O. I. Tolmachev and Dr. Yu. L. Slominskii (Institute of Organic Chemistry of NAS of Ukraine). $2 \mathrm{mM}$ dye stock solution was prepared in DMF.

Insulin fibril formation. Human insulin (Private Joint Stock Company «On the production of insulin «Indar», Ukraine) was dissolved at $340 \mu \mathrm{M}$ concentration in $100 \mathrm{mM}$ water solution of $\mathrm{HCl}(\mathrm{pH} 2)$. Fibrils were formed by incubating the protein solution in a water bath at $65^{\circ} \mathrm{C}$ for about $5 \mathrm{~h}$. Aliquots of the reaction mixture were withdrawn from each tube at about 90, 150, 240, and $300 \mathrm{~min}$ intervals to allow spectral measurements using dye 7519 . For this, $10 \mu \mathrm{l}$ aliquots of the aggregation mixture were added to $1 \mathrm{ml}$ of a $2 \mu \mathrm{M}$ dye solution in $50 \mathrm{mM}$ Tris- $\mathrm{HCl}$ buffer, $\mathrm{pH} 7.9$, insulin concentration was thus $3.4 \mu \mathrm{M}$ [7]. The dye 7519 was earlier shown to bind specifically to the fibrillar form of insulin accompanied with sharp increase in fluorescence intensity. Since the dye specifically binds predominantly to the aggregated form of insulin (both fibrillar and oligomeric) we believe the dye fluorescence intensity to be an adequate characteristic to estimate the quantity of aggregated protein (the free dye demonstrates much lower emission intensity as compared to its bound form). All spectroscopic measurements were made immediately after mixing the protein and dye solutions. Fluorescence spectra were registered using fluorescent spectrophotometer Cary Eclipse («Varian», Australia).

Inhibitory assay. The phthalocyanines PcHfPiromelit, $\mathrm{PcHfDbm}_{2}, \mathrm{PcHfPyr}_{2}, \mathrm{PcHfBtfa}_{2}$ and $\mathrm{PcHfCl}_{2}$ were added to the corresponding insulin solution right prior 


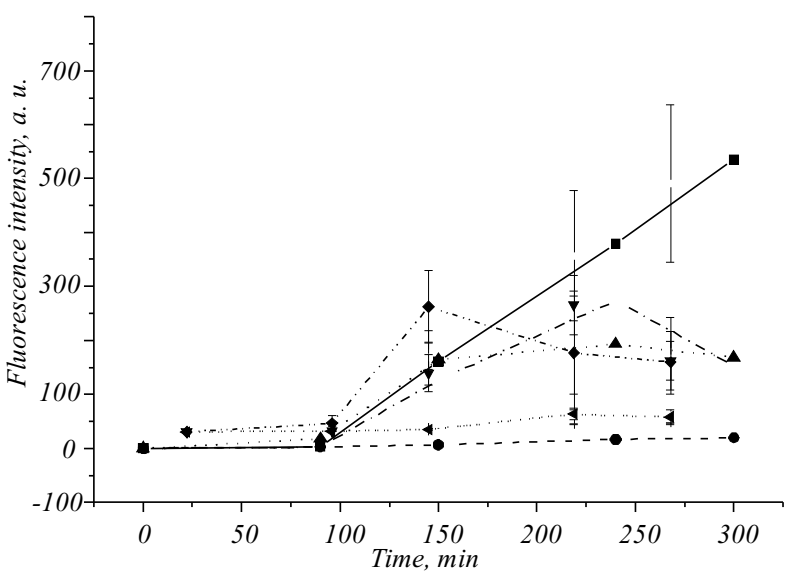

Fig. 2. Effects of presence of PcHfPiromelit (2), $\mathrm{PcHfBtfa}_{2}$ (3), PcHf $\mathrm{Pyr}_{2}(4), \mathrm{PcHfDbm}_{2}(5)$ and $\mathrm{PcHfCl}_{2}(6)$ on the kinetics of insulin fibrils formation, plotted with phthalocyanine-free insulin control $(K-$ 1). The reaction mixture containing $340 \mu \mathrm{M}$ of insulin in $0.1 \mathrm{M}$ water solution of $\mathrm{HCl}$ and $100 \mu \mathrm{M}$ of corresponding inhibitor was incubated at $65^{\circ} \mathrm{C}$ for $5 \mathrm{~h}$. Fibril formation efficiency was assessed with fluorescence intensity of dye 7519 using $2 \mu \mathrm{M}$ concentration. Experiment was performed three times. Standard deviation of the mean is presented as the error bars

the beginning of aggregation reaction. The used concentration of monomeric insulin was $340 \mu \mathrm{M}$, the concentration of inhibitors was $100 \mu \mathrm{M}$. The procedure of insulin fibrillization was performed, and the quantity of the formed aggregates was monitored using the 7519 dye fluorescence as described above.

Inhibitory activity was defined as $\left(1-I / I_{0}\right) \cdot 100 \%$, where $I_{0}$ and $I$ are the 7519 fluorescence intensity values for inhibitor-free and inhibitor-containing insulin solutions respectively. The ratio $I / I_{0}$ was considered to be an adequate estimation of quantity of protein aggregated in the presence of certain inhibitor concentration Cinh as compared to noninhibited fibrillization process. The inhibitor-free sample was used as aggregation reference; corresponding aliquot of DMF was added to this sample to exclude the solvent effect.

Absorption spectroscopy. Absorption spectra were recorded using Specord M-40 spectrophotometer («Carl Zeiss», Germany). Phthalocyanines were studied in $50 \mathrm{mM}$ Tris- $\mathrm{HCl}$ buffer, $\mathrm{pH} 7.9$ and in $0.1 \mathrm{M} \mathrm{HCl}$ (concentration range $0.5-10 \mu \mathrm{M}$ ); in DMSO (concentration $5 \mu \mathrm{M}$ ); and in the presence of $34 \mu \mathrm{M}$ native or fibrillar insulin (concentration $10 \mu \mathrm{M}$ ).

Results and discussion. Inhibitory activity of phthalocyanines in insulin fibrillization reaction. The kinetics of insulin fibrillization in the presence and in the ab- sence of phthalocyanines was monitored by the changes in fluorescence intensity of amyloid-sensitive dye 7519 according to the method described earlier [6].

With the passing of insulin fibrillization reaction we observed the changes in dye fluorescence intensity upon addition of inhibitor-free samples and samples containing compounds $\mathrm{PcHfDbm}_{2}, \mathrm{PcHfBtfa}_{2}, \mathrm{PcHfPyr}_{2}$ (Fig. 2). The presence of samples containing complexes PcHfPiromelit and $\mathrm{PcHfCl}_{2}$ slightly affected the fluorescence intensity of dye during the reaction pathway.

Thus it could be concluded that the presence of phthalocyanines with spatial substituents containing multiple phenyl groups $\left(\mathrm{PcHfDbm}_{2}, \mathrm{PcHfBtf}_{2}, \mathrm{PcHfPyr}_{2}\right)$ partially suppressed the formation of insulin fibrils. For these compounds the values of inhibition efficiency (defined as $\left(1-I / I_{0}\right) \cdot 100 \%$; see Experimental section) varied in the range $\mathrm{PcHfBtfa}_{2}(60 \%)<\mathrm{PcHfPyr}_{2}(66 \%)<$ $\mathrm{PcHfDbm}_{2}(73 \%)$.

At the early stage $(t=150 \mathrm{~min})$ of the insulin aggregation reaction in the presence of the sample containing phthalocyanine $\mathrm{PcHfDbm}_{2}$ it was demonstrated a higher dye emission comparing with inhibitor-free sample. Thus, we can suppose that the presence of $\mathrm{PcHfDbm}_{2}$ promotes the formation of beta-pleated structures at the early stage comparing with inhibitor free sample. The ability of phthalocyanines with out-of-plane ligands to redirect the insulin fibrillization reaction to the formation of spherical aggregates was shown earlier.

A higher inhibitory activity was noted for phthalocyanines PcHfPiromelit and $\mathrm{PcHfCl}_{2}$. Their presence almost completely suppressed the formation of both betapleated insulin aggregates at the early stages of reaction and amyloid fibrils. The final inhibitory effects for these complexes were about 94 and $96 \%$ correspondingly.

This observation points to the dependence of inhibitory activity of phthalocyanines on the chemical nature of out-of-plane ligand. Thus the conclusion can be made about high antifibrillogenic properties of the complexes with «small size» ligand $\left(\mathrm{PcHfCl}_{2}\right)$ or ligand containing carboxy group (PcHfPiromelit) that allows the electrostatic interaction or hydrogen bonds formation with protein aminoacids.

Determination of the efficient inhibitory concentration for PcHfPiromelit. Phthalocyanine PcHfPiromelit demonstrated a high anti-fibrillogenic activity in the insulin fibrillization reaction, thus for this complex the 


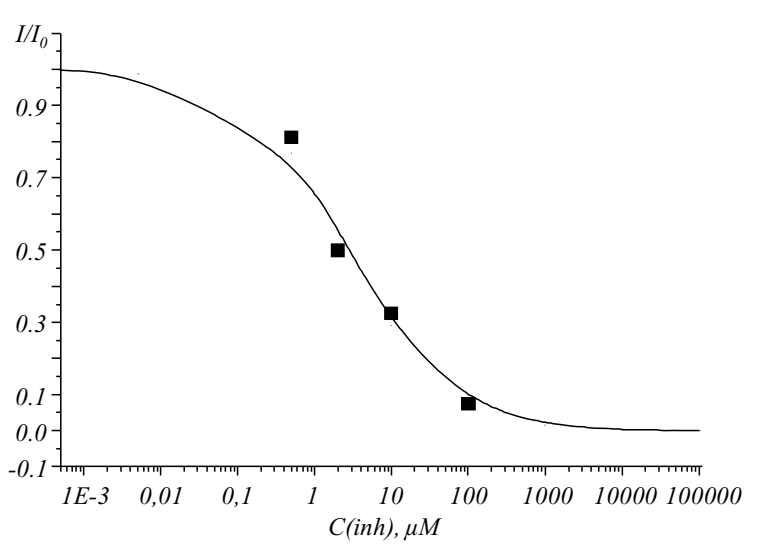

Fig. 3. Dose-dependent inhibition of insulin aggregates formation by PcHfPiromelit. The reaction mixtures containing $340 \mu \mathrm{M}$ of insulin in $100 \mathrm{mM} \mathrm{HCl}$, and $0,0.5,2,10$, or $100 \mu \mathrm{M} \mathrm{PcHfPiromelit} \mathrm{were} \mathrm{incu-}$ bated at $65{ }^{\circ} \mathrm{C}$ for $5 \mathrm{~h}$. Fibrillogenesis efficiency at the given inhibitor concentration was assessed with 7519 fluorescence emission $(I)$. The emission intensity in the absence of inhibitor $\left(I_{0}\right)$ was regarded as $100 \%$. Experimental dependence (squares) was approximated by the sigmoid dependence (line). The approximation parameter $X_{0}$ equals $(Y=1 /(1+$ $\left.\left.+\left(x / x_{0}\right)^{\wedge} d x\right) ; x_{0}=2.8 \pm 0.6 ; d x=0.7 \pm 0.1\right)$ to the efficient inhibitor concentration

efficient inhibitor concentration was identified according to the method described in [6]. The efficient inhibitor concentration is estimated as a concentration of phthalocyanine at which the dye fluorescence intensity is half concentraion for the inhibitor free solution. It is shown that the inhibitory effect enhances with increasing concentration of metal complex in the reaction mixture. The dependence of $I / I_{0}$ on $C$ (inh) for PcHfPiromelit is presented in Fig. 3.

Approximation of experimental dependence of $I / I_{0}$ on $C$ (inh) with the sigmoid curve gives the efficient inhibitor concentration $\mathrm{IC}_{50}$ which characterizes the inhibition of the fibrillization reaction by the studied metal complex. The efficient inhibitor concentration for PcHfPiromelit was determined as $\mathrm{IC}_{50}=2,8 \pm 0,6 \mu \mathrm{M}$, that is more that one order lower than the corresponding value (obtained for inhibition of bovine insulin) for zirconium phthalocyanine containing out-of-plane lysine ligands $\mathrm{PcZr}$ $\mathrm{Lys}_{2}\left(\mathrm{IC}_{50}=37 \pm 0,6 \mu \mathrm{M}\right)$, determined by us earlier [6].

Aggregation of phthalocyanines in buffer, $p H$ 7.9, and DMSO. To study the aggregation ability of phthalocya nines, we recorded their absorption spectra in polar solvent DMSO and in 0.05 M Tris-HCl buffer (pH 7.9) (Fig. 4).

In the spectra of complexes in DMSO two bands were observed, short-wavelength vibronic satellite band with maximum near $615 \mathrm{~nm}$ and sharp intensive longwavelength band with maxima on 679-693 $\mathrm{nm}$. The profiles of spectra and band positions are typical for monomeric phthalocyanines.

In absorption spectra of complexes in the buffer the bands are much wider than in DMSO. They contain two bands, short-wavelength band or shoulder in the range $642-646 \mathrm{~nm}$ and long-wavelength one in the range 685$700 \mathrm{~nm}$.

It is shown that for $\mathrm{PcHfBtfa}_{2}$ (Fig. 4, B), PcHfD $\mathrm{bm}_{2}$, and $\mathrm{PcHfPyr}_{2}$ the long-wavelength band is the most pronounced and that an increase in the complex concentration does not lead to redistribution of intensities between the absorption bands. This behavior points to a low propensity of phthalocyanines to self-association. For these complexes the absorption spectra correspond to the monomeric phthalocyanine molecules, the short-wavelength band could be attributed to the vibronic transition. The inhibitory activity of these complexes varies in the range $60-73 \%$.

In spectra of phthalocyanines PcHfPiromelit (Fig. 4, A) and $\mathrm{PcHfCl}_{2}$ in buffer, the relative intensity of short-wavelength band increases at higher complex concentration, while that of long-wavelength band decreases. Starting from about $5 \mu \mathrm{M}$ concentration the shortwavelength band dominates in the spectra. Such behavior is an evidence of high tendency of the PcHfPiromelit and $\mathrm{PcHfCl}_{2}$ metal complexes to self-association. In this case the short-wavelength band belongs to aggregates of phthalocyanines, while the long-wavelength one corresponds to their monomers. At the same time, these complexes demonstrated a very high inhibitory activity $96 \%$ for PcHfPiromelit and $94 \%$ for $\mathrm{PcHfCl}_{2}$.

In this way we observed a higher anti-fibrillogenic activity for phthalocyanines with pronounced tendency to self-association.

An addition of native or fibrillar insulin to the complex with high inhibitory activity PcHfPiromelit leads to the significant decrease of short-wavelength aggregation band and increase of long-wavelength monomeric one (Fig. 5, A). Thus it could be concluded that phthalocyanine interacts with both native and fibrillar proteins and this interaction leads to the destruction of metal complex self-associates. It is supposed that phthalocyanine molecules bind to the surface of protein in monomeric form. 

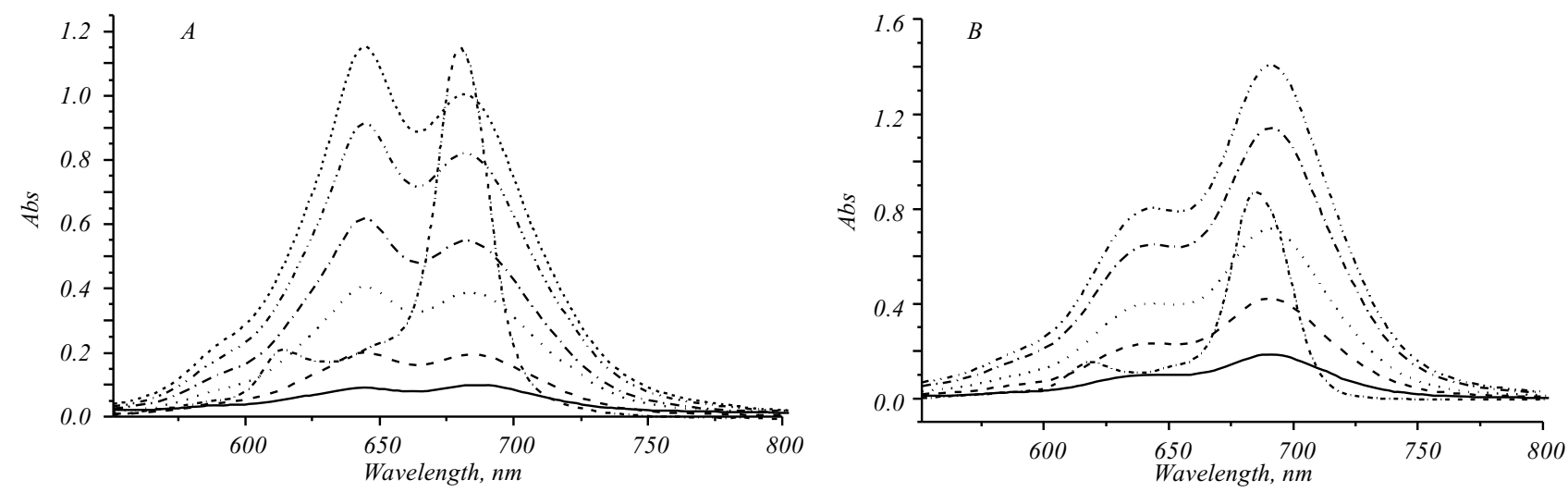

Fig. 4. Absorption spectra PcHfPiromelit $(A)$ and $\mathrm{PcHfBtfa}_{2}(B)$. Spectra are shown for concentrations of $A$ : $1-0.5 \mu \mathrm{M} ; 2-1 \mu \mathrm{M} ; 3-2 \mu \mathrm{M} ; 4-5 \mu \mathrm{M} ; 5-$ $8 \mu \mathrm{M} ; 6-10 \mu \mathrm{M} ; 7-5 \mu \mathrm{M}$, DMSO; $B: 1-1 \mu \mathrm{M} ; 2-2 \mu \mathrm{M} ; 3-5 \mu \mathrm{M} ; 4-8 \mu \mathrm{M} ; 5-10 \mu \mathrm{M} ; 6-5 \mu \mathrm{M}$, DMSO in Tris-HCl (pH 7.9) and $5 \mu \mathrm{M}$ in DMSO
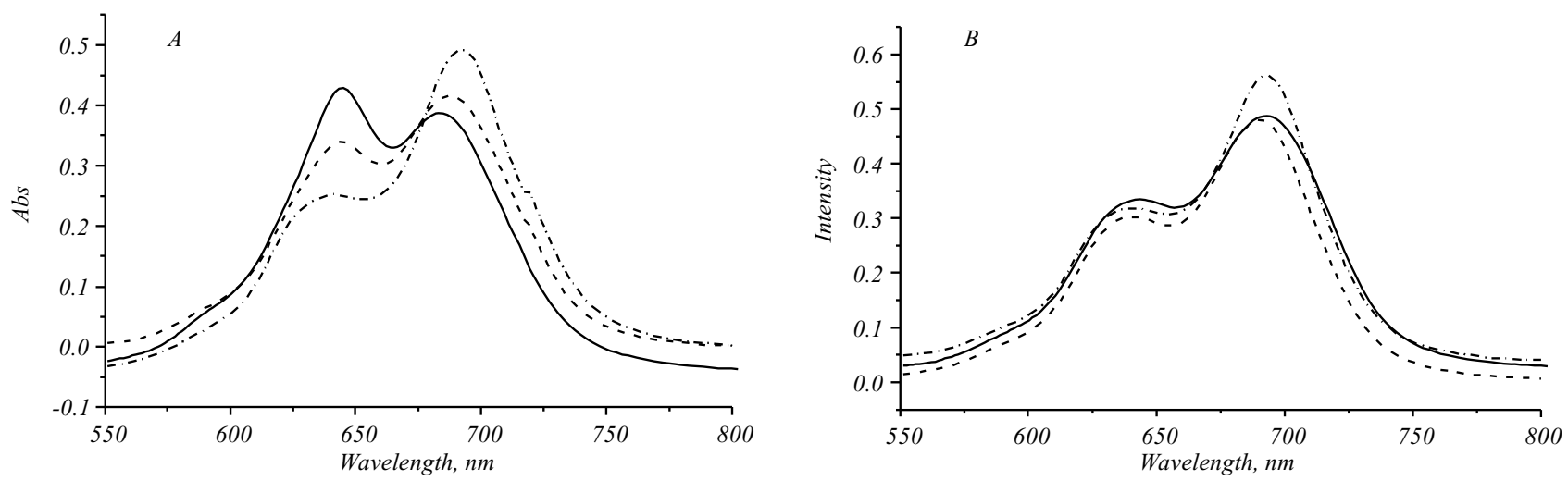

Fig. 5. Absorption spectra of PcHfPiromelit (1, concentration $10 \mu \mathrm{M})$ in the presence of native (2) and fibrillar insulin $(3$, concentration $34 \mu \mathrm{M})$ in buffer $(A)$ and in $0.1 \mathrm{M} \mathrm{HCl}(B)$

Aggregation of phthalocyanines upon conditions of fibrillization reaction. Since the reaction of insulin fibrillization is performed in acidic media $-0.1 \mathrm{M} \mathrm{HCl}$, the aggregation tendency of phthalocyanines in these conditions was studied. In absorption spectra of all studied metal complexes in acidic media the short-wavelength band (near $650 \mathrm{~nm}$ ) was observed as less intensive shoulder, while the long-wavelength band (maximum about $700 \mathrm{~nm}$ ) was the most pronounced. Besides, an increase in the phthalocyanines concentration up to $10 \mu \mathrm{M}$ did not lead to the redistribution between intensities of short- and long-wavelength bands (Fig. 6). Thus, the observed absorption spectra belong mainly to monomeric form of the phthalocyanine. Therefore, we can suppose that irrespectively of the prone of phthalocyanines to self-association in aqueous buffer at neutral or low-basic $\mathrm{pH}$, these complexes did not form aggregates in acidic media at low $\mathrm{pH}$.
It is shown that in acidic media for phthalocyanine with high inhibitory activity PcHfPiromelit the presence of native or fibrilar insulin slightly affects the relation between intensities of short- and long-wavelength absorption bands (Fig. 5, $B$ ) and thus - the aggregation degree of metal complex.

Hence, we can conclude that in acidic media the metal complexes exist mostly in monomeric form and their interaction with proteins does not cause the additional des truction of phthalocyanine self-associates or formation of associates on protein surface.

The axial coordination with imidazole ring of histidine was reported among the mechanisms of complex formation of $\mathrm{Zn}$ (II) phthalocyanine tetrasulfonate molecules and protein $\alpha$-synuclein [4]. For studied phthalocyanines we can exclude the possibility of their chemical binding to aminoacids due to the nature of metal atoms and the presence of spatial out-of-plane ligands. 

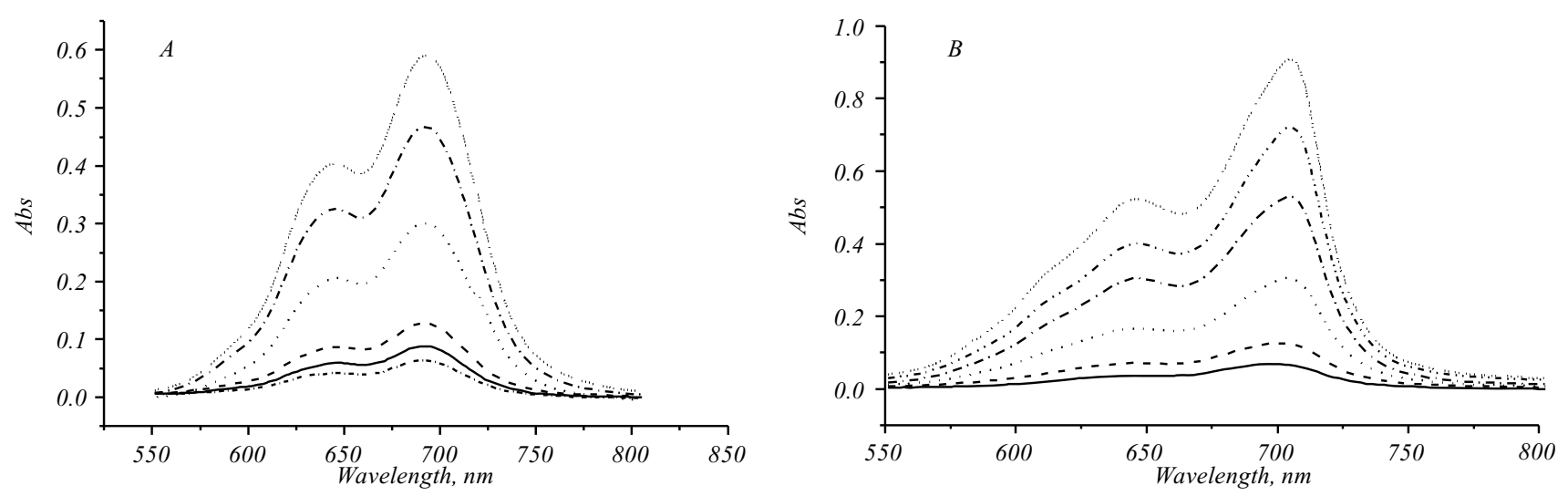

Fig. 6. Absorption spectra of PcHfPiromelit $(A)$ and PcHfCl2 $(B)$ in $0.1 \mathrm{M} \mathrm{HCl}$. Spectra are shown for concentrations of: $1-0.5 \mu \mathrm{M} ; 2-1 \mu \mathrm{M} ; 3-$ $2 \mu \mathrm{M} ; 4-5 \mu \mathrm{M} ; 5-8 \mu \mathrm{M} ; 6-10 \mu \mathrm{M}$

We propose that high self-association ability of phthalocyanines in aqueous media points to a strong stacking interaction between molecules of the metal complex. In the presence of protein the stacking of phthalocyanine molecules with aromatic aminoacids could become more preferable than self-stacking, that results in the destruction of phthalocyanine aggregates and fixation of the metal complex molecules on the surface of protein. We could further suppose that even in acidic media where the aggregation does not occur, the stronger stacking between metal complexes and aromatic amino-acids still takes place leading to the inhibition of insulin fibrillization

At the same time, the compounds with less pronounced tendency to stacking interactions poorly form selfassociates and weakly bind with aromatic amino-acids. Therefore, the tendency of phthalocyanines to selfassociation in aqueous media is considered as «an indicator» of their ability to stack with aromatic aminoacids of protein and thus their anti-fibrilogenic activity.

Conclusions. Series of hafnium phthalocyanines containing out-of-plane ligands were firstly studied as anti-fibrillogenic agents using the fluorescent cyanine dye inhibitory assay.

For the compounds with weak proneness to selfassociation in aqueous media $\left(\mathrm{PcHfDbm}_{2}, \mathrm{PcHfPyr}_{2}\right.$, PcHfBtfa ${ }_{2}$ ) the value of inhibitory activity varies in the range $60-73 \%$. For the complexes with the pronounced tendency to self-association in water solution ( $\mathrm{PcHfPiromelit}$ and $\mathrm{PcHfCl}_{2}$ ) the inhibitory activity was noticeably higher (about $95 \%$ ). For the complex PcHfPiromelit the micromolar efficient inhibitor con- centration $\left(\mathrm{IC}_{50}=2.8 \pm 0.6 \mu \mathrm{M}\right)$ in the insulin fibrillization reaction was determined.

The addition of native or fibrilar insulin to the aggregation-prone phthalocyanines in aqueous buffer leads to the destruction of self-associates of metal complex. We can suppose that phthalocyanines interact with protein through the stacking with aromatic aminoacids in monomeric form. Upon the conditions of insulin fibrillization reaction $(0.1 \mathrm{M} \mathrm{HCl})$ phthalocyanines exist predominantly as monomers, the addition of native or fibrilar insulin does not affect the degree of self-association of metal complexes.

Thus, we conclude that low-order self-associates are not involved directly in the mechanism of inhibition of insulin fibrillization, phthalocyanines bind with protein in monomeric form through the stacking to it aromatic amino-acids. We suggest that the tendency of phthalocyanines to self-association in aqueous media is «an indicator» of the proneness of metal complex molecules to stack with aromatic amino-acids of protein and thus of their anti-fibrilogenic activity.

Acknowledgements. This work was supported by STCU-NASU project N 5508.

\section{В. Б. Ковальська, М. Ю. Лосицький, С. В. Черній, В. Я. Черній, I. М. Третьякова, С. М. Ярмолюк, С. В. Волков}

Антифібрилогенна активність фталоціанінів 3 позаплощинними лігандами: кореляція зі схильністю до самоасоціації

Резюме

Мета. Дослідити активність n'яти фталоціанінів гафнію, щзо містять позаплощчинні ліганди як інгібітори реакції фібрилоутворення інсуліну, та встановити кореляцію між інгібіторними властивостями фталоціанінів і їхньою схильністю до самоасоичіа- 
ції. Методи. Флуоресцентна спектроскопія і спектроскопія електронного поглинання. Результати. Для комплексів РcHfDbm, $\mathrm{PcHfPyr}_{2}$ i PcHfBtfa, які практично не утворюють агрегатів у водному буфері, інгібіторна активність становить 60-73\%. Фталоиіаніни PcHfPiromelit i $\mathrm{PcHfCl}_{2}$ з високою схильністю до утворення агрегатів практично повністю пригнічують формування амілоїдних фібрил інсуліну (інгібіторна активність приблизно $95 \%$ ). У водному буфері за присутності мономерного або фібрилярного інсуліну відбувається руйнування агрегатів металокомплексів. Крім того, за умов проведення реакиї фібрилізаціі інсуліну $(0,1 \mathrm{M} \mathrm{HCl)} \mathrm{фталоціаніни} \mathrm{існують} \mathrm{переважно} \mathrm{у} \mathrm{вигляді}$ мономерів. Висновки. Фталоціаніни з позаплощинними лігандами з тендениією до самоасоиіації демонструють вищу інгібувальну активність у реакиії фібрилізації інсуліну порівняно з металокомплексами, які агрегують гірше. Фталоиіанінові самоасоиіати низького порядку безпосередньо не залучені до механізму інгібування агрегатоутворення інсуліну, тобто фталоиіанін зв'язується з білком у мономерній формі. Тенденцію до самоасоціації фталочуіанінів у водному середовищі можна розглядати як «індикатор» $\ddot{x}$ ньої схильності до взаємодї з ароматичними амінокислотами $i$, отюе, як показник їхньої антифібрилогенної активності.

Ключові слова: амілоїдні фібрили, фталочіаніни, інгібітори фібрилоутворення, інсулін, агрегація фталочіанінів, флуоресиентний барвник.

В. Б. Ковальская, М. Ю. Лосицкий, С. В. Черний, В. Я. Черний, И. Н. Третьякова, С. Н. Ярмолюк, С. В. Волков

Антифибриллогенная активность фталоцианинов с внеплоскостными лигандами: корреляция со склонностью к самоассоциации

\section{Резюме}

Цель. Исследовать активность пяти фталоцианинов гафния, содержащих внеплоскостные лиганды в качестве ингибиторов реакции фибриллообразования инсулина, и установить корреляцию между их ингибиторными свойствами и склонностью к самоассоциации. Методы. Флуоресцентная спектроскопия и спектроскопия электронного поглощения. Результаты. Для комплексов $\mathrm{PcHfDbm}_{2}, \mathrm{PcHfPyr}_{2}$ и PcHfBtfa, практически не образующчи агрегатов в водном буфере, ингибиторная активность составляет 60-73\%. Фталоичанины PcHfPiromelit u $\mathrm{PcHfCl}_{2}$ с высокой склонностью к образованию агрегатов практически полностью подавляют формирование амилоидньх фибрилл инсулина (ингибиторная активность около $95 \%$ ). В водном буфере в присутствии мономерного или фибриллярного инсулина происходит разрушение агрегатов металлокомплексов. Кроме того, в условиях проведения реакции фибриллизации инсулина $(0,1 \mathrm{M} \mathrm{HCl})$ фталоцианины существуют преимущественно в виде мономеров. Выводы. Фталоцианины с внеплоскостными лигандами с тенденцией к самоассоциации демонстрируют высокую ингибирующую активность в реакции фибриллизации инсулина по сравнению с металлокомплексами, агрегируюшими хуже. Фталочианиновые самоассоциаты низкого порядка непосредственно не вовлечень в механизм ингибирования агрегатообразования инсулина, т. е. фталочианин связывается с белком в мономерной форме. Тенденциию к самоассоциации фталоцианинов в водной среде можно рассматривать как «индикатор» их склонности ко взаимодействию с ароматическими аминокислотами и, следовательно, как показатель их антифибриллогенной активности.
Ключевые слова: амилоидные фибрилль, фталоцианины, ингибиторы фибриллообразования, инсулин, агрегация фталоцианинов, флуоресиентный краситель.

\section{REFERENCES}

1. Uversky V. N., Fink A. L. Conformational constraints for amyloid fibrillation: the importance of being unfolded // Biochim. Biophys. Acta.-2004.-1698, N 2.-P. 131-153.

2. Kelly J. W. The alternative conformations of amyloidogenic proteins and their multi-step assembly pathways // Curr. Opin. Struct. Biol.-1998.-8, N 1.-P. 101-106.

3. Lamberto G. R., Binolfi A., Orcellet M. L., Bertonconi C. W., Zweckstetter M., Griesinger C., Fernandez C. O. Structural and mechanistic basis behind the inhibitory interaction of PcTS on alpha-synuclein amyloid fibril formation // Proc. Natl Acad. Sci. USA.-2009.-106, N 50.-P. 21057-21062.

4. Caughey W. S., Raymond L. D., Horiuchi M., Caughey B. Inhibition of protease-resistant prion protein formation by porphyrins and phthalocyanines // Proc. Natl Acad. Sci. USA.-1998.-95, N 21.-P. 12117-12122.

5. Lamberto G. R., Torres-Monserrat V., Bertosecini C. W., Salyatella X., Zweckestetter M., Griesinger C., Fernandez C. O. Toward the discovery of effective polycyclic inhibitors of alphasynucleine amyloid assembly // J. Biol. Chem.-2011.-286, N 37.-P. 32036-32044.

6. Caughey W. S., Priola S. A., Kocisko D. A., Raymond L. D., Ward A., Caughey B. Cyclic tetrapyrrole sulfonation, metals, and oligomerization in antiprion activity // Antimicrob. Agents Chemother.-2007.-51, N 11.-P. 3887-3894.

7. Kovalska V., Losytskyy M., Chernii V., Volkova K., Tretyakova I., Cherepanov V., Yarmoluk S., Volkov S. Studies of anti-fibrillogenic activity of phthalocyanines of zirconium containing out-of-plane ligands // Bioorg. Med. Chem.-2012.-20, N 1.P. 330-334.

8. Volkova K. D., Kovalska V. B., Inshin D., Slominskii Y. L., Tolmachev O. I., Yarmoluk S. M. Novel fluorescent trimethine cyanine dye 7519 for amyloid fibril inhibition assay // Biotech. Histochem.-2011.-86, N 3.- P. 188-191.

9. Chernii V. Ya., Bon V. V., Tretyakova I. N., Severinovskaya $O$. $V$., Volkov $S$. $V$. Novel zirconium (IV) and hafnium (IV) phthalocyanines with dibenzoylmethane as out-of-plane ligand: Synthesis, X-ray structure and fluorescent properties // Dyes Pigm.2012.-94, N 2.-P. 187-194.

10. Gerasymchuk Y. S., Volkov S. V., Chernii V. Ya., Tomachynski L. A., Radzki St. Synthesis and spectral properties of axially substituted zirconium(IV) and hafnium(IV) water soluble phthalocyanines in solutions // J. Alloys Compd.-2004.-380, N 1-2.P. 186-190.

11. Tomachynski L. A., Tretyakova I. N., Chernii V. Ya., Volkov S. V., Kowalska M., Legendziewicz J., Gerasymchuk Y. S., Radzki St. Synthesis and spectral properties of $\mathrm{Zr}(\mathrm{IV})$ and $\mathrm{Hf}(\mathrm{IV})$ phthalocyanines with $\beta$-diketonates as axial ligands // Inorg. Chim. Acta.-2008.-361, N 9-10.-P. 2569-2581.

12. Volkova K. D., Kovalska V. B., Losytskyy M. Yu., Fal K. O., Derevyanko N. O., Slominskii Y. L., Tolmachov O. I., Yarmoluk $S$. M. Hydroxy and methoxy substituted thiacarbocyanines for fluorescent detection of amiloid formation // J. Fluoresc.2011.-21, N 2.-P. 775-784. 